\title{
Custom Hiring Services of Power Thresher for Small-Farm Rice Threshing in Kampar Regency, Indonesia
}

\author{
Ujang Paman, Saipul Bahri and Asrol \\ Department of Agribusiness Faculty of Agriculture Riau Islamic University. Pekanbaru, Riau, Indonesia. \\ E-mail:u_paman@yahoo.com; saipulbahri.uir@gmail.com;asrolmkh67@yahoo.com
}

\begin{abstract}
The availability of power thresher for custom hiring services has accelerated the mechanical power use in small-scale rice threshing operation in Kampar Regency. This research attempts to determine the need, used capacity, and seasonal work of power thresher and to analyze the cost, profit, and break-even of power thresher hire services managed by farmer groups. Data were collected from 15 power threshers from 10 custom-hiring services group selected using purposive sampling technique in seven districts of Kampar Regency. The interviews with group managers, custom operators, and mechanics were conducted during the main growing season in 2012. The results showed that the number of power threshers on farmer groups was limited and most of them, however, still worked under capacity. The power thresher was employed only for group members with custom work about 64.9 $\mathrm{t} / \mathrm{season}$. The seasonal work was more than break-even point of about $7.7 \mathrm{t} / \mathrm{season}$, so the custom-hiring services of power thresher are profitable. Therefore, the method can become an alternative source of income and also extend the power thresher adoption amongst rice farmers in the region.
\end{abstract}

Keywords - Custom hiring services, power thresher, small-farm rice threshing, Kampar Regency.

\section{INTRODUCTION}

Threshing operation is often the most important agricultural task facing farmers in rice production system. The operation is a major aspect that is carried out after harvesting of grain crops [1]. The threshing which involves separation of paddy from panicles is a laborious task [2] and consumes 25 percent of the total energy utilized in paddy cultivation [3]. Moreover, the use of traditional methods for paddy threshing, such as treading by feet, beating on threshing boards or racks, and using pedal thresher, are always time consuming and uneconomical [4] or involves high labor costs with low efficiency and higher field losses [5]. The traditional threshing method causes grain loss to the extent of 6 percent [6]. The main cause of losses is the inefficient equipment used in the post-production system [7].

With the increase of mechanization on farms today, paddy threshing has become highly mechanized and this leads to the development of custom-hiring services. Currently, the custom hiring services have become an important method to provide power thresher for small farmers without their own the machine. It is because the low annual hours of thresher used in small-scale farming can cause to be dificult to justify the ownership of the machine for exclusive use on own farm. So, although the seasonal work was relatively low, the use of power thresher with hiring services can be profitable. This method has also helped the small farmers to take up the farm operation with farm machinery without going in for investment in high cost machinery [8]. Farm machinery hire services for hand tractor in Riau have been reported [9].

In Kampar regency, the method has been widely adopted in many rice-growing areas and has helped farmers to timely complete threshing operation with a lower grain loss and higher efficiency. Custom hire services managed by farmer groups are prevalent in the Kampar Regency [10]. The farmer groups do not only manage power threshers but also other machines such as power tillers, cultivators, water pumps, dryers, and RMUs. Based on data reported by Food Crops Service of Kampar Regency [11], there are 43 hire services groups in 12 of the 21 districts in the regency.

Custom hire service is a farm machinery business that must be managed effectively and efficiently in order to make profit for the groups. The availability of custom hire services becomes important for sustaining the mechanization process in order to meet food self-sufficiency. The present paper attempts to determine the need, used capacity, and seasonal work of power threshers and to analyze the cost, profit, and break-even of power thresher hire services managed by farmer groups. 


\section{MATERIALS AND METHODS}

A field survey of power thresher use in paddy threshing was conducted in ten villages from seven districts in Kampar Regency during rainy growing season of 2013. The rainy season is the main growing season in this regency, as rice crop is feasible on $100 \%$ of the available land area. The locations were selected to represent an average condition for the rice threshing system adopted in the regency. Purposive sampling technique was used to select 15 power threshers from the areas. The power threshers selected had actively been hired for rice threshing operations in recent years.

Primary and secondary data were collect from different methods and sources. Primary data were collected by interviewing with group manager and power threshers' operators through the use of a structured questionnaire. The data collected consisted of information on machine age, purchase price, interest rates, seasonal works, daily working hours, seasonal working days, custom rates, operator wages, fuel, oil, and lubricant costs, spare part replacement, and repair costs. Furthermore, secondary data were gathered from food crops service and statistical offices of Kampar regency and Riau Province. The data collected were analyzed by using simple statistical techniques such as percentage and mean and a simple cost accounting method.

\section{RESULTS AND DISCUSSION}

\section{A. Paddy threshing methods}

The methods which are used by farmers for threshing rice in Kampar Regency are beating on threshing boards or racks, threshing by pedal thresher, and using power thresher (Fig. 1). Although the use of threshing board and pedal thresher is still dominant, power thresher is more and more popular among farmers today.The entire document should be in Times New Roman or Times font. Type 3 fonts must not be used. Other font types may be used if needed for special purposes. Recommended font sizes are shown in Table 1.

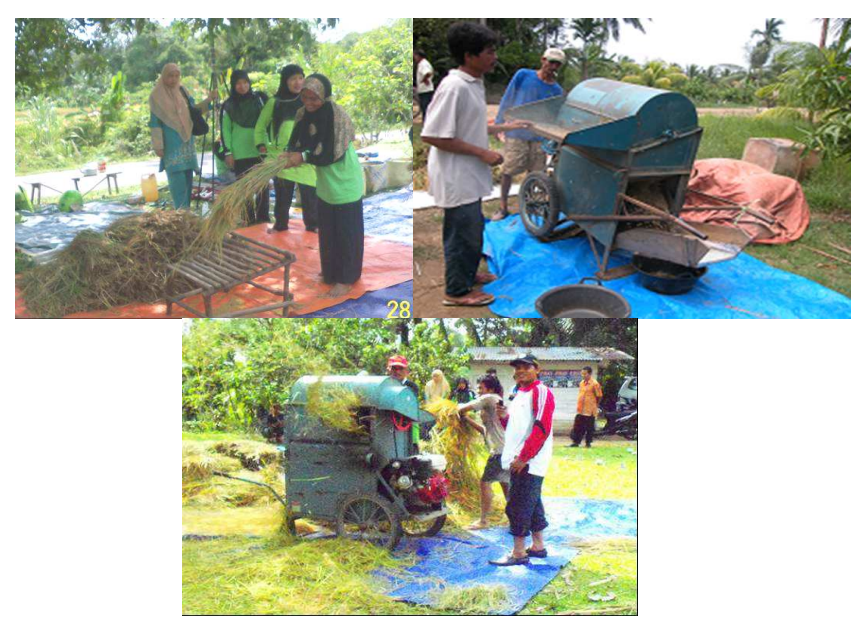

Fig. 1 Three paddy threshing methods in Kampar Regency

The reasons of rice farmers for using the power thresher are that the machine save labor and time, has a higher capacity, and reduce grain loss, damage, and drudgery. Consequently, farmers in the region are becoming more dependent on power thresher to complete the threshing operation. This leads to increase demand for the thresher hire services in the region.

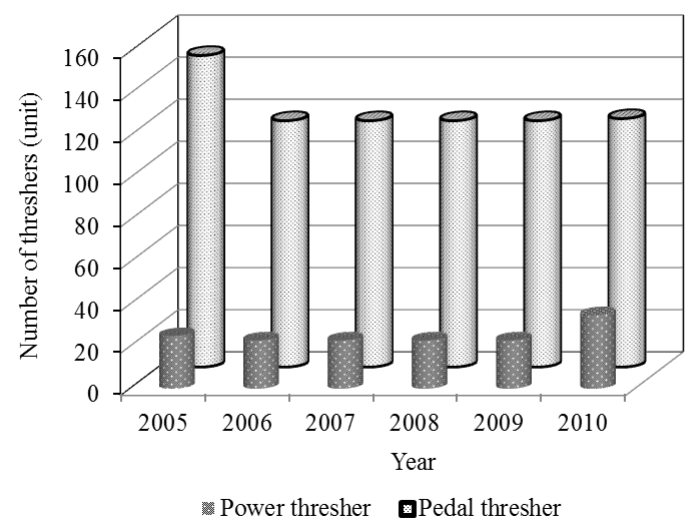

Fig. 2 Development of pedal and power threshers during a period of $2005-2010$.

Fig. 2 shows the development of pedal thresher and power thresher during a period of 2005-2010. The pedal thresher is, in fact, still an important tool for threshing rice in Kampar Regency. It can be seen that the number of the available pedal thresher was more than the power thresher during the period, but decreased at the rate of 5\% annually. However, the number of power thresher increased at about $5 \%$ annually during the same period. The result indicates that rice farmers have regularly replaced of using pedal thresher to power thresher. It is important to accelerate technology transfer from human power technology to mechanical power technology which is more performance, effective, and efficient.

\section{B. Seasonal work and capacity}

According to Table 1. the power thresher worked less than one month, i.e. only 16.7 days per season with 7.1 hours per day on average. This working day is lower than national average of 25 days per season. The seasonal work was $9,192 \mathrm{~kg}$ with working capacity of $542.32 \mathrm{~kg} / \mathrm{h}$. Based on the seasonal work; it means that the machine can thresh rice grain about $550 \mathrm{~kg} /$ day. In addition, the working capacity of the power thresher was less than the machine capacity available, ranging from $600 \mathrm{~kg}$ to $700 \mathrm{~kg}$ per hour. Discussion with respondents revealed that the operator skill and machine age affected the working capacity of power thresher.

TABLE I

MACHINE-WiSE SEASONAL WORKING DAY, SEASONAL WORK AND WORKING CAPACITY

\begin{tabular}{|l|r|r|}
\hline Item & Value & \multicolumn{1}{|c|}{ National* } \\
\hline Working day per season (day) & 16.70 & 25 \\
\hline Working hour per day (h) & 7.10 & 8 \\
\hline Seasonal work (ha/season) & 9,192 & - \\
\hline Working capacity (kg/h) & 542.31 & $600-800$ \\
\hline \multicolumn{2}{|c}{} \\
\hline Sources: Anonymous [12]
\end{tabular}

The number of power threshers in the group was not adequate enough to thresh the entire coverage area of the group members. From figure 6 , the total coverage area per group ranged from 42 ha for Zoki Busami to 400 ha for Tani Maju with average of 175 ha. Assuming the power thresher works at $30 \mathrm{ha} /$ season; it is needed to about 5 power 
threshers per hire service group to thresh the whole coverage areas. Because about 4 power threshers to complete the requirement. Consequently, approximately $12 \%$ of the coverage area on average was worked by power threshers and the remaining $88 \%$ was worked by pedal threshers or other traditional tools.

Figure 3 also shows that the working area worked by available power threshers varied from $3 \%$ for Tani Maju to $38 \%$ for Zoki Busamo. Besides the limited number of machines owned, the use of pedal threshers and traditional methods by farmers was also the reason for the low coverage area. Although pedal threshers and traditional methods (e.g., beating a bunch of panicles against a wooden board) are becoming increasingly unpopular among farmers, many farmers still own such equipment and use it for threshing rice. Even though it was considered impractical to use such equipment due to their high energy consumption, the farmers deemed them the most economical.

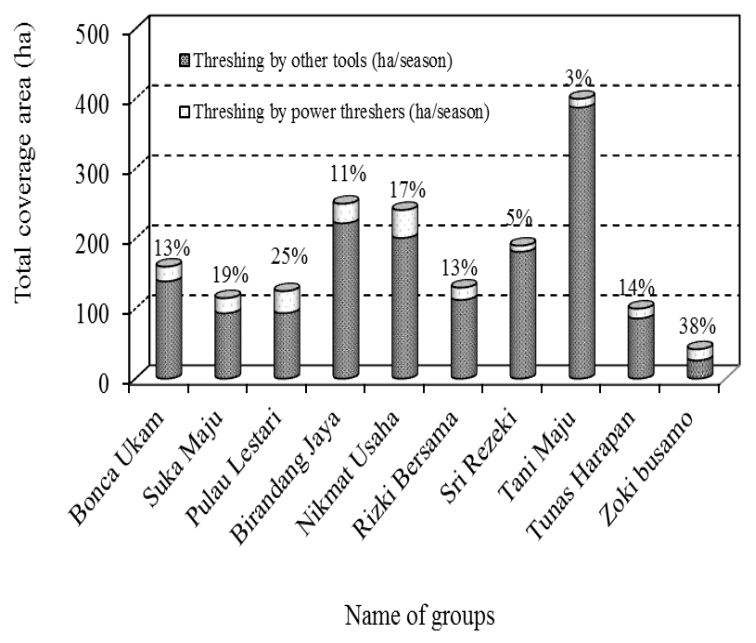

Fig. 3 Group-wise coverage area worked by power threshers

\section{Costs of using power thresher}

Costs were determined on a per-season basis, in terms of both fixed and variable costs. Fixed costs were computed to include losses resulting from depreciation and interest on investments. Depreciation can be estimated by several ways, as described by [13]. The most realistic and simplest method for estimating depreciation is the straight-line method [14]. For this study, depreciation was estimated as purchase price minus salvage value, divided by the number of years of useful life. Five years was assumed to be the rational economic life of power thresher in the survey area. Salvage value was assumed to be $10 \%$ of the purchase price. Interest was determined by taking one half the purchase prices plus the salvage value, and multiplying this sum by the $6 \%$ prevailing interest rate in the survey area. Variable costs included all expenditures for fuel, oil, lubricant, repair, maintenance, and operator wages. Repair costs included both the materials and labor required to carry out repairs [15].
TABLE II.

AVERAGE COST, REVENUE, PROFIT AND BREAK-EVEN POINT OF POWER THRESHER HIRING SERVICE

\begin{tabular}{|l|r|c|}
\hline Item & \multicolumn{1}{|c|}{ Value } & Percentage \\
\hline Fixed cost (IDR) & $1,019,077$ & 61.33 \\
\hline Variable costs (IDR) & 642,582 & 38.67 \\
\hline Total costs (IDR) & $1,661,659$ & 82.54 \\
\hline Custom rate (IDR/kg) & 223 & - \\
\hline Seasonal work (kg) & 9,192 & - \\
\hline Total revenue (IDR) & $2,013,048$ & 100.00 \\
\hline Profit (IDR) & 351,389 & 17.46 \\
\hline Break-even (kg) & 7,238 & 83.47 \\
\hline
\end{tabular}

Table 2 presents a summary of seasonal cost estimates of fixed and variable costs for power thresher. It was found that the largest cost was fixed costs, contributing for about $61 \%$ (IDR 1.02 million) of the total costs of 1.66 million per season. These costs consisted of depreciation and interest, contributing for about $42 \%$ and $19 \%$, respectively (Fig. 4). While, the variable costs contributed to about $39 \%$ (IDR 0.64 million) of the total costs. Operator wage alone was the largest cost of the variable costs, contributing for about $21 \%$, followed by repair and maintenance costs of about $11 \%$ of the total costs.



Fig. 4 Relative importance of all cost components for power thresher hiring service operations.

Furthermore, the revenue per season was computed by multiplying the seasonal work per season by custom rate per $\mathrm{kg}$. Based on Table 2, the total revenue obtained was 2.01 million with custom rate of IDR $223 / \mathrm{kg}$. The average profit, which was calculated by subtracting the total costs from the total revenue, was found to be IDR 351,389 per season, contributing for about $17 \%$ of the total revenue. It means that the power thresher hire services is profitable. 


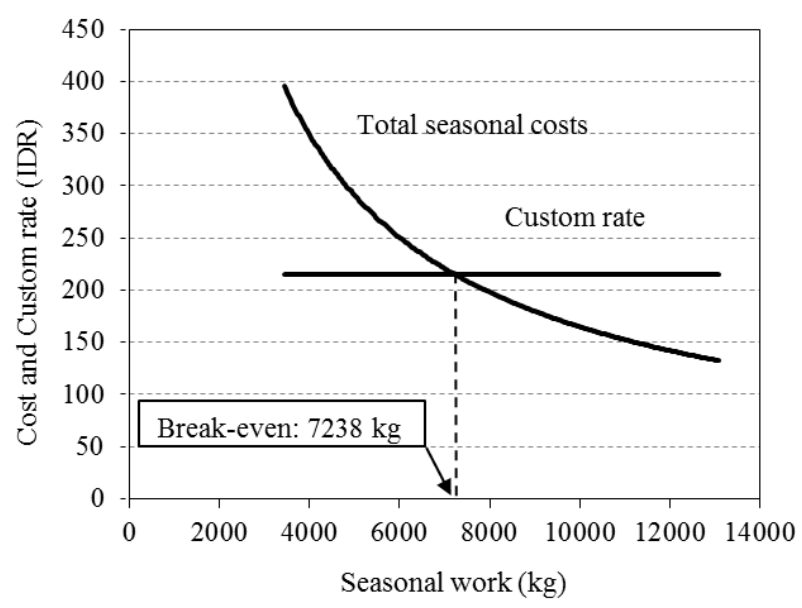

Fig. 5 Break-even analysis of power thresher hiring service operation

\section{CONCLUSIONS}

Seasonal thresher use required for economic viability can be known by break-even analysis. Table 2 and Fig. 5 present the break-even point calculated in this study. According to Butterworth and Nix [14], the break-even area can be calculated by dividing the fixed cost per season by the difference in custom rate and average variable cost per hectare. The calculation result showed that the break-even point would be achieved on seasonal work of $7,238 \mathrm{~kg}$, while the actual average of the seasonal work was $9,192 \mathrm{~kg}$. The break-even of seasonal work is about $79 \%$ of the actual seasonal work. It indicates that power thresher hiring services, on the average, made a profit from their operations on small-scale rice farming.

\section{REFERENCES}

[1] Olugboji, O. A. "Development of a rice threshing machine," AU J.T., Vol. 8, No. 2, pp. 75-80. 2004

[2] Khushk, A.M. and Lashari, M.I. (2006) Returns on paddy threshing. DAWN the internet edition. August 14, Edited by Nasir, A. Pakistan: DAWN groups of News papers. [online]. Available: http://www.dawn. com/2006/08/14/ebr6.htm.

[3] Kathrivel K, and S Sivakumar, Empowerment of women in agriculture. coordination committee report of AICRP on ergonomics and safety in Agriculture. Tamil Nadu Agricultural University, India, 2003.

[4] Hossain, M B., M A. Hossain, and B C. "Nath. Feasibility study of motor and engine driven open drum power thresher," Eco-friendly Agri. Journal, Vo. 6, No. 5, pp. 83-92, 2013.

[5] Annamalai, S. J. K. "Mechanization of harvesting and threshing operations in rainfed crops - Issues and Strategies," Indian Journal of Dryland Agricultural Research \& Development, Vol. 19, No. 1, pp. 24-30, 2004.

[6] Miah, M.A.K; Roy, B.C. Hafiz, M.A. Haroon, M and Siddique, S.B. "Comparative study on the effect of rice threshing methods on grain Quality," Aagricultural Mmechanization in Asia, Africa and Latin America (AMA), Vol. 25, No. 3, pp. 63-66, 1994.

[7] De Padua, D. B. Postharvest Handling in Asia. Agricultural Engineering Division, International Rice Research Institute (IRRI), Philippines, 2003.

[8] Singh, S., H. S. Kingra and Sangeet. "Custom hiring services of farm machinery in Punjab: iimpact and policies," Indian Research Journal and Extension Education, Vol. 13, No. 2, pp. 45-50, 2013.

[9] Paman, U., S. Uchida, and S. Inaba. "Economic potential of tractor hire business in Riau Province, Indonesia: A case study of small tractors for small rice farms," Agricultural Engineering International: CIGR Journal, Vol. 12, No. 1, pp. 135-142, 2010.

[10] Paman, U., S. Inaba, and S. Uchida. "Farm machinery hire services for small farms in Kampar Regency, Riau Province, Indonesia," Applied Engineering in Agriculture, In Press, 2014.

[11] Food crops service of Kampar Regency. Annual Report. Bangkinang, 2012.

[12] Anonymous. (2014) Alat dan mesin pertanian. Available: http://id.wikipedia.org/wiki/Alat_dan_me sin_pertanian.

[13] Hunt, D. Farm power and machinery management. 8th edition. Iowa State University Press, Iowa, USA, 2001.

[14] Butterworth, B. and J. S. Nix. Farm mechanization for profit. Granada, London, 259 p, 1983.

[15] Fairbanks, G. E., G. H., Larson, and D. S. Chung, "Cost of using farm machinery". Transactions of the ASAE, Vo. 14, No. 1, pp. 98$101,1971$. 